\title{
INTRODUCTION
}

\section{Teacher's Perception towards Usage of Social Media To Enhance Teaching Performance}

\section{Dr. Shazia Shahab Shaikh" ${ }^{1^{*}}$ iD | Dr. Abida Hafeez ${ }^{2}$ iD Ziauddin $^{3}$}

\section{Abstract}

The study directs to analyze the perception of teachers towards the adaption of social media as a new technology for the enhancement of teaching performance. The collected data contains a sample of $n=130$ faculty members of two public universities of Sindh province of Pakistan. Technology Acceptance Model (TAM) has been used in the framework of the study. The data were analyzed by the Smart Partial Least Square (PLS) software version 3. The aggregate response from the teacher's rate is $94.7 \%$ for the current study. More than an average social networking source, Whatsapp mostly used $58.46 \%$ by the teachers of public universities. The teachers of public universities use $92.31 \%$ of Facebook and $67.69 \%$ of Whatsapp less than four hours per day. Acceptable AVE and CV are indicating acceptable scores. A value of SRMR below 0.08 is a depiction of good fit. The study confirmed all the established hypotheses indicating the factors including Perceived Usefulness and the Perceived Ease of Use and towards teachers' performance and satisfaction are significantly affected by the use of social media. Therefore, the study finds a stronger association of social media use to Perceived ease of usefulness. It is al so observed that the Perceived Usefulness and Perceived Ease of Use appear crucial fuctors to make a significant prediction about teachers' performance after using social media in Pakistan.

Keywords: Perceived Ease of Use, Teacher Performance, Social Media, Perceived Usefulness,

\section{Author's Affiliation:}

Institution: University of Sindh, Jamshoro ${ }^{1}$ | University of Education, Lahore ${ }^{2}$ | University of Karachi

Country: Pakistan

Corresponding Author’s Email: *shazia.shahab@usindh.edu.pk

The material presented by the author(s) does not necessarily portray the view point of the editors and the management of the ILMA University, Pakistan.

(Print) 2707-8906 (online) 2788-8304 $\odot 2021$, published by the ILMA University, Pakistan.

This is open access article under the @( license. https://creativecommons.org/licenses/by-nc-sa/4.0
Social media usage in respect of communication cannot be denied. Almost everyone is using social networking sites such as; Facebook, Whatsapp, Youtube, and Twitter. Social media usage is beneficial in business, marketing, social awareness, entertainment, news updates, banking, and especially in educational purposes. Since the last decades, social media sites have increased unbelievable attractiveness among teachers. Social media applications are also using for communication, sharing of information, collaborative learning, and teaching too. Social media has provided a large platform for discussion, sharing information and
knowledge. Higher education faculties are utilizing social media sites in order to interact with colleagues, students along with professional purposes. Professors are frequently using Whatsapp and Facebook in assigning to students for academic tasks and sharing content in developed and developing countries. Regarding online teaching in developing countries, Jogezai et al (2021) found that social media has teaching in developing countries, Jogezai et al (2021) found that social media has significantly affected the teacher's attitude toward online education while pandemic. (Jogezai et al., 2021).

Another study by Van et al (2020) reviewed that social media is suitable for constructivistapproaches oflearning amongteachers, students, and parents. Alhumaid et al (2020) reveal a positive relationship between social media and the technology acceptance model during Covid-19 in Pakistan. However, teachers expressed an encouraging opinion concerning e-learning acceptance during lockdown situations in the pandemic of the country (Alhumaid et al., 2020).

Jain (2019) says that there are seven ways of social media can be used by the professor \& students in learning and teaching perspective. The first is collaborative learning and information sharing via social media sites helps teachers to foster teaching pedagogy, research, and continue teaching from everywhere and any time. As an educator, it is easy and cheap access to interact with teachers with students. In this context, Ebner et al. (2010) depict that educators have found an alternative fascinating platform of social media in the affordable learning atmosphere.

Bolat (2018) depicts that in the cultural, socio-economic development of the country, social media has become a driving force. This network extends the social contacts of people. He further says that social media networks are being improved their sphere of influence in a lot of fields, like banking, health, defense, entertainment, and advertisement, particularly in education. He finds in his study that teachers use social media 2 to 4 hours daily; they like to use an android mobile phone. Moreover, both Instagram and Facebook are the most popular networks of social media among teachers.

Bexheti et al. (2014) presented an analysis on the teachers of southeast European University and found that the majority of teachers were well aware of social media networks. The study proved that teachers used social media networks as a beneficial
tool for enhancing teaching performance and collaborative learning with each other. Their study concluded that teachers were most affected by social media networking; 
they shared, created, found, and learned knowledge with the collaboration.

Regarding the awareness of social media sites, Moran et al. (2011) argued that all faculty members of higher education in the US are aware of social media sites. In respect of usage of social media networking, they find that overall $90 \%$ of Higher education in the US is using social media sites in subject teaching and in professional careers too. Universities teachers are the most frequent user of Facebook \& YouTube (Moran et al. 2011). An instructional Technologist, Steven W. Anderson cited by . the people for professional development that they want to do".

In Nigeria, Morrison et al. (2017) reveal that Nigerian business teachers appreciate social media use as a source of instruction in education.

Social media can be beneficial in the enhancement of teachers' teaching performance and social media diminish the communication loopholes.

Scholars agree that Facebook, Whatsapp, and Twitter are the advanced social media tools of communication adopted by professional businessmen, teachers, and students. Social media has the potential to become a valuable resource of educational collaboration and communication among universities teachers. The entire institutions particularly universities faculty members are more in interaction with the latest communication technologies to interact with colleagues, students, friends, and family members (Moran 2011; Manca \& Ranieri, 2017).

Social media improves academic performance and solves social and academic issues during socialization (Khattak, 2016). The usage of social media is rapidly increasing in education particularly at the universities level. The study of Khan et al. (2017) was presented an analysis regarding the social media role on the teaching performance of teachers in Punjab and KPK and found that the usage of various sites of social networking in the field of education improved the performance of teachers in teaching. Such research studies have not been done before in the higher education institutions like the universities of Sindh province of Pakistan. Therefore, to fulfill the loophole in research, it is mandatory to analyze the perception of higher education faculties in respect of enhancement of teacher's teaching performance.

\section{Objectives of the Study}

The aim of the present study is to explore the teacher's perception towards the inclination of social media usage in the field of social sciences in public universities. However, it is also mandatory to explore the role of social media to improve the teacher's teaching performance.

Many studies have been accomplished on the effective usage of social media teachers' teaching performance but this study has been determined the perceptions of social sciences teachers regarding social media use particularly Facebook \& Whatsapp for the enhancement of teaching performance and satisfaction at the university level of the country.

\section{Hypothesis}

The following hypotheses have been established

H1: Social media usages influence teachers' perceived usefulness towards teaching performance of universities.

$\mathrm{H} 2$ : Social media usages influence teachers' perceived ease to use towards teaching performance of universities.

H3: Perceived ease to use of social media influences teacher's performance towards satisfaction of teacher's teaching in universities.

H4: Perceived usefulness influences teacher's learning performance towards satisfaction in teaching at the level of universities.

H5: Teachers' teaching performance influences their teaching satisfaction by using social media in universities.

\section{Significance of the study:}

The present study may be significant in recognizing the use/role of social media along with its benefits to teachers' teaching performance. Teachers of universities will be enlightened the beneficial social media role inclined towards teaching performance solves barriers and achieve fulfillment in teaching performance.

2. Uses of Social Media among Universities Teachers

In fact, social media has been widely involved by the higher education faculty members in pedagogies worldwide (Moran et al., 2011)

A plethora of studies show that university teachers use social media means like Whatsapp and Facebook in teaching all over the world. The majority of teachers are in favor of the use/role of social media in educational institutes and most of the teachers engage themselves in learning more application of social media in education perspective in Nigeria (Morrison et al., 2017).

Social media sites are providing new patterns to educators in the light of encouraging, fostering, and enhancing social constructivist learning (Manca \& Ranieri, 2017). Social media attracts billion of users due to easy access and affordability (Salvation \& Adzharuddin, 2014)

In Saudi Arabia, even middle school students and teachers acknowledge that they operate social media via smartphones to complete academic tasks timely. According to statistics, 73 percent of students and 100 teachers use Whatsapp as a communication tool. Also, they prefer to use social media for foreign direct investment, education, and socialization purposes (AlabdullKareem, 2015).

Teachers use various tools of social media and agree to the barriers and benefits of it and it has no negative effects on the social status of members of various faculties 
who exercise social media while teaching (Abdelraheem et al., 2015). Moran et al.(2011) reveal that "two-third of faculty members use social media during classes. Social media have valuable tools of videos, podcasts, and wikis for teaching and collaborative learning as well.

Generally, all faculties belong to higher education are mindful of social media role/ use (Nemetz, 2012). Roblyer, et al. (2010) explain that Facebook is widely adopted by the students and having the potential to collaborative learning with teachers. On another side, Roblyer, et al. (2010) also find that teachers mostly prohibit the use of technologies in the classroom. Further, the study reveals that teachers use only Facebook for personal or educational purposes. They mostly prefer to communicate via email and traditional technologies with their peers and students.

Social media is a new technology and scholars accepted the usages of social media sites are useful in the education sector in respect of teaching and learning perspectives. Khan, et al. (2017) exhibited that social media had a significant impact on the teaching performance of teachers. Further, they proposed that social media sites enhanced teachers' teaching performance. Khan, et al. (2017) cited the study of Schwartz (2009), which explored that "the social media as a ubiquitous tool that can be used everywhere for any purpose but nowadays it is using in education most effectively because it enhances the capabilities and skills of faculties as well as the learning abilities of students". The majority of faculties believe in social media. TAM (Technology Acceptance Model) is employed in the framework of the study.

\section{METHODOLOGY AND MODEL SPECIFICATION}

Many studies have been investigated the students' perception of e-learning adoption (Habes et al., 2019). On the other hand, very few studies have been conducted to explore the perception of teachers towards the use of social media in public universities of Sindh province of Pakistan. To explore this phenomenon, the researchers have adopted the Technology Acceptance Model (TAM) with the affirmed hypothesis of the study. The Technology Acceptance Model has explained perceived ease of use and perceived usefulness in terms of influence on teachers' performance and satisfaction.

The study explores the perception of teachers regarding the use of social media in teaching performance in the two public universities of Sindh province of Pakistan. The University of Sindh, Jamshoro, and the University of Karachi are the oldest universities in the country. The study determines that teachers accept or reject the new technology from a teaching perspective. In this regard, Technology Acceptance Model (TAM) has been used in the framework of the study. Scholars acknowledge that social media technology is useful in enhancing teaching performance among teachers. The study seeks to analyze the perception of teachers about the acceptance of the new technology, social media, and usage of social media for the enhancement of teaching performance. The data is analyzed by the Smart Partial Least Square (PLS) software version 3. Thus, diagram 1 below shows the Technology Acceptance Model (TAM) before the Covid-19 pandemic.

\section{Population and Sample Size}

In this study, the population consists of only social sciences faculty members of the two public sector universities including the University of Sindh and the University of Karachi. These two public universities are being chosen for the following reasons: i. The geographical diversity is reflected in the sampled universities belonging to the Sindh province of Pakistan, which are located in urbanized areas of the Sindh. ii. The University of Sindh and the University of Karachi are selected because they are larger universities in the metropolitan cities of the Sindh province and students come from all rural and urban surrounding areas, cover huge geographical areas.

The sample size of the study was comprised only faculty members of the universities level. However, due to certain limitations, including the availability of the teachers, the researchers have selected a convenient sampling method. The researchers have chosen sample $n=130$ respondents of two public universities of Sindh province of Pakistan. The data were analyzed by the Smart Partial Least Square (PLS) software version 3

\section{TECHNOLOGY ACCEPTANCE MODEL (TAM)}

The Technology Acceptance Model (TAM) is a widely used model in the adaptation of new technology for educational purposes. Scholars agreed that teachers adapt new technology in education. In this regard, Hong, Zhang, and Liu (2021) found that Chinese teachers adapted new technology towards the improvement of education. TAM (Technology Acceptance Model) was originated by Fred Davis in 1985 (Mugo et al., 2017). The model (i.e. TAM) was produced by Davis in 1989, to understand the causal relationships between internal attitudes, intention and believes of users. David has explained and predicted the acceptance of computer-based technology (Devis et al., 1989). (Refer to Figure 1).

The behavioural intention is decided through PEOU (Perceived Ease Of Use) and PU (Perceived Usefulness), which are based on the attitude of users (Amadu et al., 2018). TAM theorizes that both PEOU and PU determine the behavioural intention of individuals to utilize such a system (Amadu et al, 2018). The purpose of the TAM is to observe that the perception and attitudes of the users of communication technology affect their rejection or acceptance of technology (Refer to Figure 1).

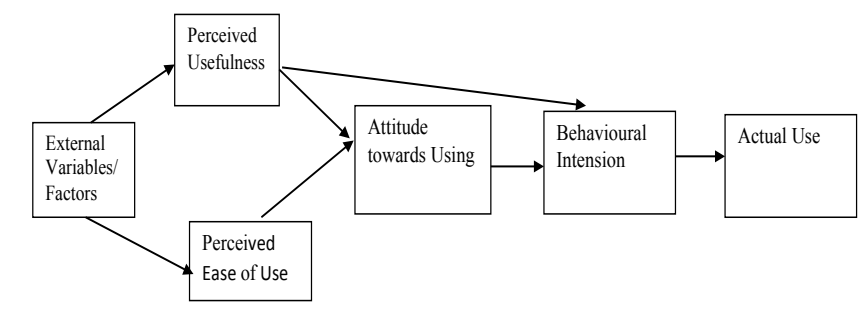

Figure 1. TAM (A model proposed by Davis et al., 1989) 
In this present study, we have modified the social media technology acceptance model which is never being used before in the case of media studies. It explores the effect of perceived usefulness and perceived ease of use of social media technology in teaching performance. We use this model (i.e. TAM) on the basis of these factors and the conceptual framework for the study is following:

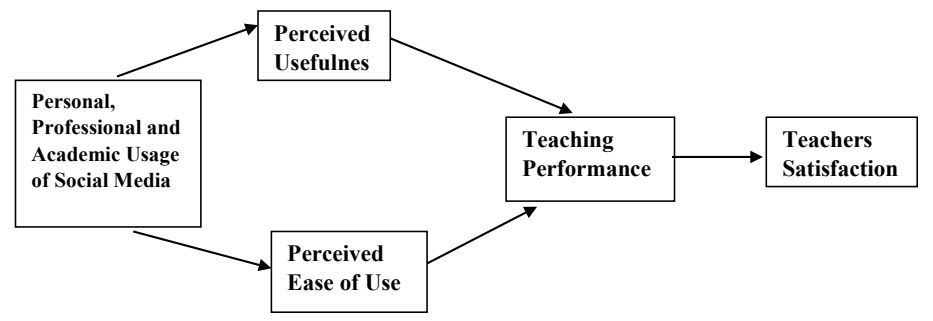

Figure 2. Conceptual Model

The conceptual model is designed to prove that how teachers come to understand and adopt the new technology. This framework describes that how teachers use the technology for the betterment of their teaching performance and satisfaction. The main factors of the conceptual framework are Social Media Technology (SMT), Perceived Usefulness (PU), Teaching Performance (TP), and Perceived Ease of Use (PEOU) along with Satisfaction by Teaching (SBT). According to Davis (1989) "Perceived Usefulness (PU) is the degree to which a user believes that using a particular system would enhance his or her job performance".

\section{DESCRIPTION OF DATA}

Table 1 given below shows demographic and descriptive statistics of data.

Teachers of two public universities of Sindh are the sampled population in this research. Therefore, 150 questionnaires were distributed, 142 were returned, and out of 142 , only 130 questionnaires were appropriated for interpretation of data. The 12 questionnaires were discarded because of a lack of completeness and missing information by the respondents. The aggregate response from the teacher's rate is $94.7 \%$ for the current study. More than an average social networking source i.e. Whatsapp mostly used $58.46 \%$ by the teachers of public universities. The teachers use $92.31 \%$ of Facebook and $67.69 \%$ Whatsapp less than four hours per day. (Refer to table 1)

\section{Table I: Demographic Profile}

\begin{tabular}{|c|c|c|c|}
\hline University & Gender & $\begin{array}{c}\text { Frequen- } \\
\text { cy } \\
\end{array}$ & Percentage \\
\hline \multirow[t]{3}{*}{ University of Sindh } & Male & 32 & $49.230 \%$ \\
\hline & Female & 33 & $50.76 \%$ \\
\hline & Total & 65 & $100 \%$ \\
\hline \multirow[t]{3}{*}{ University of Karachi } & Male & 32 & $49.230 \%$ \\
\hline & Female & 33 & $50.76 \%$ \\
\hline & Total & 65 & $100 \%$ \\
\hline \multirow[t]{3}{*}{ Gender } & Male & 64 & $49.23 \%$ \\
\hline & Female & 66 & $50.76 \%$ \\
\hline & Total & 130 & $100 \%$ \\
\hline \multirow{2}{*}{ Social Networking Use } & Yes & 128 & $98.46 \%$ \\
\hline & No & 2 & $1.54 \%$ \\
\hline \multirow{5}{*}{$\begin{array}{l}\text { Social networking used } \\
\text { source }\end{array}$} & Facebook & 33 & $25.38 \%$ \\
\hline & Whatsapp & 76 & $58.46 \%$ \\
\hline & Twitter & 13 & $10.00 \%$ \\
\hline & Skype app & 9 & $6.92 \%$ \\
\hline & Zoom app & 31 & $23.85 \%$ \\
\hline \multirow[t]{4}{*}{$\begin{array}{l}\text { Frequency of using } \\
\text { Facebook }\end{array}$} & $\begin{array}{c}\text { Less Than } 4 \text { hrs/ } \\
\text { day }\end{array}$ & 120 & $92.31 \%$ \\
\hline & $\begin{array}{c}\text { In B/W 4-8 hrs/ } \\
\text { day }\end{array}$ & 8 & $6.15 \%$ \\
\hline & $\begin{array}{l}\text { More than } 8 \mathrm{hrs} / \\
\text { day or All the day }\end{array}$ & 3 & $2.31 \%$ \\
\hline & Never & 2 & $1.54 \%$ \\
\hline \multirow[t]{4}{*}{$\begin{array}{l}\text { Frequency of using } \\
\text { Whatsapp }\end{array}$} & $\begin{array}{l}\text { Less Than } 4 \text { hrs/ } \\
\text { day }\end{array}$ & 88 & $67.69 \%$ \\
\hline & $\begin{array}{c}\text { In B/W 4-8 hrs/ } \\
\text { day }\end{array}$ & 30 & $23.08 \%$ \\
\hline & $\begin{array}{l}\text { More than } 8 \mathrm{hrs} / \\
\text { day or All the day }\end{array}$ & 12 & $9.23 \%$ \\
\hline & Never & 2 & $1.54 \%$ \\
\hline
\end{tabular}




\section{Data Analysis}

The Smart PLS Version 3 is used for testing the causal relationships among the factors.

Table 2: Teacher's Construction of Reliability

\begin{tabular}{|c|c|c|c|c|c|}
\hline Variables & Coded & $\begin{array}{c}\text { Factor } \\
\text { Load- } \\
\text { ing } \\
\end{array}$ & CR & AVE & $\begin{array}{l}\text { Cron- } \\
\text { bach's } \\
\text { alpha }\end{array}$ \\
\hline \multirow{2}{*}{ P.PF.AC } & & & 0.984 & 0.835 & 0.982 \\
\hline & PUSM 01 & 0.928 & & & \\
\hline & PUSM 02 & 0.901 & & & \\
\hline & PUSM 03 & 0.903 & & & \\
\hline & PUSM 04 & 0.873 & & & \\
\hline & PUSM 05 & 0.915 & & & \\
\hline & AUSM 01 & 0.911 & & & \\
\hline & AUSM 02 & 0.934 & & & \\
\hline & AUSM 03 & 0.925 & & & \\
\hline & AUSM 04 & 0.936 & & & \\
\hline & AUSM 05 & 0.933 & & & \\
\hline & PFUSM 01 & 0.907 & & & \\
\hline & PFUSM 02 & 0.898 & & & \\
\hline \multirow{9}{*}{$\begin{array}{c}\text { Perceived Useful- } \\
\text { ness (PU) }\end{array}$} & & & 0.985 & 0.891 & 0.982 \\
\hline & PU 01 & 0.945 & & & \\
\hline & PU 02 & 0.946 & & & \\
\hline & PU 03 & 0.943 & & & \\
\hline & PU 04 & 0.94 & & & \\
\hline & PU 05 & 0.927 & & & \\
\hline & PU 06 & 0.953 & & & \\
\hline & PU 07 & 0.957 & & & \\
\hline & PU 08 & 0.938 & & & \\
\hline
\end{tabular}

\begin{tabular}{|c|c|c|c|c|c|}
\hline \multirow{2}{*}{$\begin{array}{c}\text { Perceived Ease Of } \\
\text { Use (PEOU) }\end{array}$} & & & 0.986 & 0.856 & 0.985 \\
\hline & PEU 01 & 0.912 & & & \\
\hline & PEU 02 & 0.917 & & & \\
\hline & PEU 03 & 0.946 & & & \\
\hline & PEU 04 & 0.934 & & & \\
\hline & PEU 05 & 0.903 & & & \\
\hline & PEU 06 & 0.919 & & & \\
\hline & PEU 07 & 0.954 & & & \\
\hline & PEU 08 & 0.924 & & & \\
\hline & PEU 09 & 0.936 & & & \\
\hline & PEU 10 & 0.92 & & & \\
\hline & PEU 11 & 0.906 & & & \\
\hline & PEU 12 & 0.933 & & & \\
\hline \multirow{11}{*}{$\begin{array}{l}\text { Teaching Perfor- } \\
\text { mance (TP) }\end{array}$} & & & 0.988 & 0.896 & 0.987 \\
\hline & TP 01 & 0.932 & & & \\
\hline & TP 02 & 0.963 & & & \\
\hline & TP 03 & 0.938 & & & \\
\hline & ТP 04 & 0.957 & & & \\
\hline & TP 05 & 0.951 & & & \\
\hline & TP 06 & 0.953 & & & \\
\hline & TP 07 & 0.953 & & & \\
\hline & TP 08 & 0.959 & & & \\
\hline & ТP 09 & 0.917 & & & \\
\hline & TP 10 & 0.94 & & & \\
\hline \multirow{5}{*}{$\begin{array}{c}\text { Teacher's Satisfac- } \\
\text { tion (TS) }\end{array}$} & & & 0.979 & 0.921 & 0.972 \\
\hline & TS 01 & 0.964 & & & \\
\hline & TS 02 & 0.966 & & & \\
\hline & TS 03 & 0.948 & & & \\
\hline & TS 04 & 0.961 & & & \\
\hline
\end{tabular}




\begin{tabular}{|l|l|l|}
\hline \multicolumn{3}{|c|}{ Table 3: Fit Summary } \\
\hline & Saturated Model & Estimated Model \\
\hline SRMR & 0.034 & 0.040 \\
\hline d_ULS & 1.303 & 2.003 \\
\hline d_G & 6.430 & 6.902 \\
\hline$\chi^{2} /$ df & 2.671 & 2.726 \\
\hline
\end{tabular}

Note: $\mathrm{SRMR}=$ Root Mean Square Residual NFI= Normed Fit Index

Cronbach's Alpha is calculated in order to estimate the reliability of different variables. The minimum/lower limit of an acceptable score of Cronbach's Alpha should be 0.7 for internal consistency (Hair et al., 1995). The acceptable score of Cronbach's Alpha through reliability values has been shown in Table 2, where all values are higher than 0.7 up to .987 . Moreover, all values that appear higher than 0.7 for reliability are also acceptable. The construct validity is estimated through two types of validity: the discriminate validity along with the convergent validity, which is analyzed via CR (Composite Reliability) and AVE (Average Variance Extracted) (Fornell \& Larcker, 1981). The minimum value for Composite Reliability (CR) should be 0.7 along with an acceptable value for the AVE (Average Variance Extracted), which can be equal to 0.5 or above as highlighted by Hair et al. (2006). The loading values for all variables appear equal to 0.5 or above reaching the level of significance i.e. $\mathrm{p}<0.001$. Moreover, both AVE and CV are indicating acceptable scores.

\section{Structural Model Evaluation of Reliability and Validity}

As far as the reliability of the model is concerned, the value of SRMR reflected the fit criterion/ absolute measure of the model. A value of SRMR below 0.08 is a depiction of a good fit. The values of SRMR is 0.04 for the estimated model and 0.034 for the saturated model indicate that SRMR reflects the goodness of fit and the model is nullify misspecification as well. However, the value of NFI (Normed Fit Index) is 0.803 and 0.901 for both saturated model and estimated model respectively. The value of the estimated model is equal to a threshold value i.e. 0.90 (although its value varies from 0 to 1 and closer to 1 reflects better fit, NFI $>0.90$ for acceptable fit). The results of chi-square are less than 3 indicating goodness of fit (Hair et al. 1998). The values of both d_USL and d_G are also significant at $1 \%$ and $5 \%$ levels of significance indicating the exact fit of the model. Overall, we considered the values of the estimated model.
The values of both Adjusted R-Square and R-Square have been shown in Table 4. These values show the explanatory power of the model (showing the magnitude/ variation by which independent variables explain the dependent variables). All the dependent variables including PEOU (Perceived Ease Of Use), PU (Perceived Usefulness) along with Teaching Performance (TP), Teacher's Satisfaction (TS) are substantially explained by independent variables as all values appeared close to 1. For example, TP showing the highest explanatory power i.e. 0.946 entailing that $94.6 \%$ variation in TP is explained by independent variables.

Table 4: Results of R-Square/ Adjusted R-Square

\begin{tabular}{|c|c|c|}
\hline Variables & R-Square & Adjusted R-Square \\
\hline PEU & 0.935 & 0.935 \\
PU & 0.910 & 0.910 \\
TP & 0.946 & 0.945 \\
TS & 0.921 & 0.920 \\
\hline
\end{tabular}

\section{RESULTS OF HYPOTHESIS TESTING}

The findings from the structural model (TAM) undertaken have been exhibited through figure (3). The model after estimation gives the coefficients along with R2 (squared multiple correlations) which explains the variation caused by independent/explanatory variables in the dependent variable(s). The PU (Perceived Usefulness) towards teaching performance of universities in the model (1) is estimated under the impact of social media use, which appears significant with a value of $(\beta)=.945(\mathrm{p}<0.001)$, explaining $91 \%$ variation of the PU $(\mathrm{R} 2=$ $0.910)$. Hence, the H1 hypothesis has been proved.

The PEOU (Perceived Ease of Use) is shown the significant impact of social media use with a value $(\beta)=.967(\mathrm{p}<0.001)$. The PEOU variable explicated $93.5 \%$ of social media use towards teaching performance of universities. $(\mathrm{R} 2=93.5)$. The results confirmed the $\mathrm{H} 2$ hypothesis.

Teacher performance is estimated via PEOU (Perceived Ease of Use) with a value of coefficient $(\beta)=.305(\mathrm{p}<0.001)$ and PU (Perceived Usefulness) having a coefficient value $(\beta)=.677(\mathrm{p}<0.001)$. Both factors/variables explicated $94.6 \%$ of the Teacher performance with explanatory power i.e. R2 $=0.946$. Hence, both $(\mathrm{H} 3$ \& H4) hypotheses are confirmed.

Teacher performance exhibits significant effect with a coefficient value $(\beta)=.960$ $(\mathrm{p}<0.001)$ on Teacher satisfaction while explaining $92.1 \%$ of the variation in Teacher satisfaction $(\mathrm{R} 2=0.921)$. Therefore, the H5 hypothesis is confirmed by 
the results of the study. All the alternative hypotheses have been proved statistically significant. All coefficient values appear positive indicating the positive impact of all factors on teachers' performance.

\section{Figure 3: Structural Model Results}

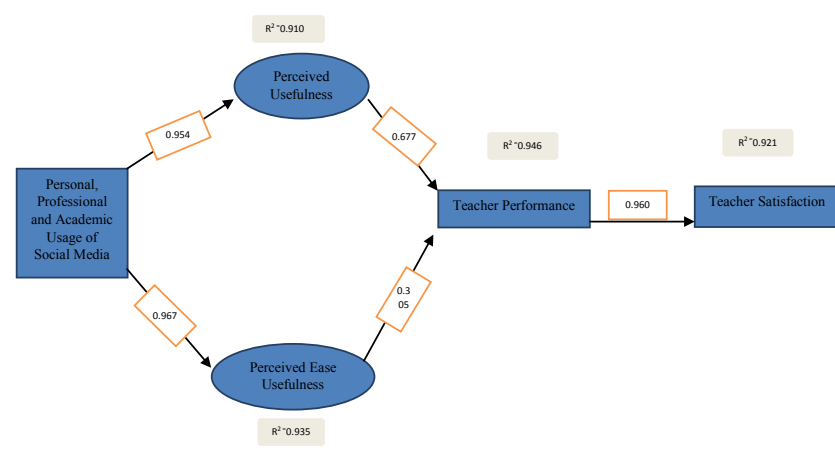

\section{CONCLUSION}

The study investigates the perception of teachers towards the use of social media while enhancing teaching performance and satisfaction of faculty members of the two public sector universities including the University of Sindh and the University of Karachi. The study directs to analyze how social media usage influences teachers 'perceived usefulness' and 'perceived ease to use of the new technology, social media, and usage of social media for the enhancement of the teaching performance as well as satisfaction at the university level. Technology Acceptance Model (TAM) is used in the framework of this study to analyze the questionnaires based data and considered appropriated for interpretation of data by the Smart Partial Least Square (PLS) software version 3. TAM supposes that both PEOU and PU determine the behavioural intention of individuals (Amadu et al, 2018). The basic purpose of the TAM is to explore the perception as well as attitudes of the users of communication technologies/various platforms of social media including Facebook, Whatsapp, Youtube, and Twitter

The aggregate response from the teacher's rate is $94.7 \%$ for the current study. Acceptable scores of Cronbach's Alpha through reliability values appear greater than 0.70 up to .987 . Moreover, both AVE and CV are indicating acceptable scores. A value of SRMR below 0.08 is a depiction of a good fit. The study confirmed all the established hypotheses given in figure 3 indicating the factors including Perceived Usefulness and the Perceived Ease of Use and towards teachers' performance and satisfaction are significantly affected by the use of social media. Therefore, the study finds a stronger association of social media use to Perceived ease of usefulness. It is also observed that the Perceived Usefulness and Perceived Ease of Use appear crucial factors to make a significant prediction about teachers' performance after using social media in Pakistan. This research is also supported by Martin (2012) and Elkaseh, et al. (2016). In conclusion, all the alternative hypotheses have been proved statistically significant. All coefficient values appear positive indicating the positive impact of all factors of teacher's perception/usages of social media explained via different established hypotheses on teacher's performance and satisfaction at the university level.

\section{REFERENCES}

Abdelraheem, A. Y, \& Ahmed, A. M. (2015). Electronic social media in teaching: Usages, benefits, and barriers as viewed by Sudanese faculty members. American International Journal of Social Science, 4(5), 58-68.

Alabdulkareem, S. A. (2015). Exploring the use and the impacts of social media on teaching and learning science in Saudi. Procedia-Social and Behavioral Sciences, 182, 213-224.

Alhumaid, K., Ali, S., Waheed, A., Zahid, E., \& Habes, M. (2020). COVID-19 \& Elearning: Perceptions \& Attitudes Of Teachers Towards E-Learning Acceptance in The Developing Countries. Multicultural Education, 6(2), 100115.

Amadu, L., Muhammad, S. S., Mohammed, A. S., Owusu, G., \& Lukman, S. (2018). Using technology acceptance model to measure the ease of social media for collaborative learning in Ghana. JOTSE, 8(4), 321-336.

Bexheti, Lejlaa A. et al.(2014). 'An Analysis of Social Media Usage in Teaching and Learning: The Case of SEEU'. Recent Advances in Electrical and Computer Engineering.

Bolat, Yaviz., (2018).'A Research on the Use of Social Media Networks by Teacher Candidates'. Journal of Curriculum and Teaching, Vol.7. (1) web link: http:// jct.sciedupress.com

Davis, F.D., Bagozzi, R.P., \& Warshaw, P.R. (1989). User acceptance of computer technology: A comparison of two theoretical models. Management Science, 35(8), pp 982-1003.

Ebner M., Lienhardt, C., Rohs, M. \& Meyer, I. (2010). 'Micro blogs in higher education- a chance of facilitate informal and process-oriented learning. Computer \& Education, 55, 92-100.

Elkaseh, A.M., Wong, K.W. and Fung, C.C. (2016) "Perceived Ease of Use and Perceived Usefulness of Social Media for e-Learning in Libyan Higher Education: A Structural Equation Modeling Analysis," International Journal of Information and Education Technology vol. 6, no. 3, pp. 192-199.

Fornell, C., \& Larcker, D. F. (1981). Evaluating structural equation models with unobservable variables and measurement error. Journal of marketing research, 18(1), 39-50. 
Habes, M., Salloum, S. A., Alghizzawi, M., \& Mhamdi, C. (2019). The relation between social media and students' academic performance in Jordan: YouTube perspective. In International Conference on Advanced Intelligent Systems and Informatics (pp. 382-392). Springer, Cham

Hair, J. F., R. E. Anderson, R. L. Tatham, and W. C. Black , (1995) Multivariate Data Analysis with Readings, New Jersey: Englewood.

Hair, J. F., R. L. Tatham, R. E. Anderson, and W. Black, (2006) Multivariate Data Analysis, Upper Saddle River, NJ: Pearson Prentice Hall, vol. 6.

Hair, J. F., R. E. Anderson, R. L. Tatham, and W. Black (1998) Multivariate Data Analysis, Upper Saddle River.

Hong X, Zhang M and Liu Q (2021) Preschool Teachers' Technology Acceptance During the COVID-19: An Adapted Technology Acceptance Model. Front. Psychol. 12:691492. doi: 10.3389/fpsyg.2021.691492

Jain, Rahul., (2019). 'Use of Social Media in Teaching and Learning: Emerging Role of Social Media and its importance in Teaching and learning'. Web link; https://www.asmaindia.in/blog/use-of-social-media-in-teaching-and-learningemerging-role-of-social-media-and-its-importance-in-teaching-and-learning.

Jogezai, N. A., Baloch, F. A., Jaffar, M., Shah, T., Khilji, G. K., \& Bashir, S. (2021). Teachers' attitudes towards social media (SM) use in online learning amid the COVID-19 pandemic: the effects of SM use by teachers and religious scholars during physical distancing. Heliyon, 7(4), e06781.

Khan, M. I.,Ahmed, M., \&Amin, A. (2017). The Impact of Social Media on Teacher's Performance: A Case of Higher Educational Institutions of Pakistan. European Online Journal of Natural and Social Sciences, 6(2), pp-206.

Khattak, Sajid., Rehman, Batool, Saima., Saleem, Zafar and Takrim Kausar..(2016). 'Effects of Social Media on Teacher's Performance: Evidence from Pakistan'. The Dialogue, 11(1)

Makau,B.M.(1988). 'Computer in Kenyan School; A Case Study of an innovation in Kenya'. Canada: IDRC.

Manca, S., \& Ranieri, M. (2017). Implications of social network sites for teaching and learning. Where we are and where we want to go. Education and Information Technologies, 22(2), 605-622.

Martin, R. G. (2012). Factors affecting the usefulness of social networking inElearning at German University of Technology in Oman. International Journal of e-Education, e-Business, e-Management and e-Learning, 2(6), 498.

Moran, M., Seaman, J., \& Tinti-Kane, H. (2011). Teaching, Learning, and Sharing: How Today's Higher Education Faculty Use Social Media. Babson Survey
Research Group.

Morrison, J. L., Oladunjoye, G. T., Oyedele, J., \& Maman, J. (2017). The Utilization of Social Media in the Classroom by Business Teacher Educators in Nigeria. African Journal of Teacher Education, 6.

Mugo, D. G., Njagi, K., Chemwei, B., \& Motanya, J. O. (2017). The technology acceptance model (TAM) and its application to the utilization of mobile learning technologies. 20(4): pp 1-8. www.scienedomain.org

Nemetz P.L.(2012). Journal of Instruction Pedagogies, pp 1-17

Roblyer, M. D., McDaniel, M., Webb, M., Herman, J., \& Witty, J. V. (2010). Findings on Facebook in higher education: A comparison of college faculty and student uses and perceptions of social networking sites. The Internet and higher education, 13(3), 134-140.

Salvation, M., \& Adzharuddin, N. A. (2014). The influence of social network sites (SNS) upon academic performance of Malaysian students. International journal of humanities and social science, $4(10), 1$.

Schwartz, H. L.(2009). The Chronicle Review. pp1-8

Srivastava, P. (2012). Social networking \& its impact on education-system in contemporary era. International Journal of Information Technology Infrastructure, 1(2).

Van Den Beemt, A., Thurlings, M., \& Willems, M. (2020). Towards an understanding of social media use in the classroom: a literature review. Technology, Pedagogy and Education, 29(1), 35-55. 